\title{
The Role of Strategic Information Systems (SIS) in Supporting and Achieving the Competitive Advantages (CA): An Empirical Study on Saudi Banking Sector
}

\author{
Nisreen F. Alshubaily \\ Al Imam Mohammad Ibn Saud Islamic University (IMSIU) \\ Riyadh, Saudi Arabia
}

\author{
Abdullah A. Altameem \\ Al Imam Mohammad Ibn Saud Islamic University (IMSIU) \\ Riyadh, Saudi Arabia
}

\begin{abstract}
The purpose of this research paper is to identify the significant role of Strategic Information Systems (SIS) in supporting the Competitive Advantage (CA). It also explains its role on the dimensions that increase the competitive advantage which are the operational efficiency, information quality and innovation. In order to achieve the goal of this study and to collect the primary data, the researchers designed a survey, in the form of an electronic questionnaire. This survey instrument consisted of 20 questions. It was distributed to members of the study sample, which contains the managers at all levels, and the employees in the Saudi banking sector. The number of the participants included in the survey was 147 . The results of this study revealed that there is a significant role of strategic information systems on increasing operational efficiency, improving the quality of information and promoting innovation. This in turn enabled the organizations to achieve higher levels of competitive advantages. The strategic information systems have deep consequences for organizations that adopt them; managers could achieve great and sustainable competitive advantages from such systems if carefully considered and developed. On the other hand, this study was conducted in the banking sector in KSA context. So, more research is needed in other sectors and in the context of other countries; to confirm and generalize the results. Finally, the paper's primary value lies in its ability to provide the evidence that the strategic information systems play a significant role in supporting and achieving the competitive advantages in Saudi Arabia, particularly in the banking sector. Since there was a lack of such research in the Saudi context, this paper can provide a theoretical basis for future researchers as well as practical implications for managers.
\end{abstract}

Keywords-Strategic information systems (SIS); competitive advantage (CA); operational efficiency; information quality; innovation

\section{INTRODUCTION}

In the light of today's global economy, the organizations face several challenges such as globalization, privatization, stiff competition and more demanding customer expectations, coupled with daily advancement in information and communication technologies. In this environment, the top managers should understand and realize that the IS/IT is not merely a resource to support day-to-day operations. They should also realize that the clever use of IS/IT can significantly change an organization's long term strategic position in national and global markets. Therefore, it becomes increasingly imperative that the managers create new and different strategies including the change of top management for long-term planning and strategic decision-making versus the operational decision-making. Subsequently, if the organizations wish to remain successful and to be competitive, the managers need to consider Information Systems (ISs) as a tool utilized to gain competitive advantages, in order to overcome the other competitive organizations. So, the information systems that help seize opportunities of gain competitive advantages are often called Strategic Information Systems (SIS).

The strategic information system can be defined as an information system that creates or enhances the company's competitive advantage or changes the industry structure by fundamentally changing how business is conducted. It is conventional information systems used in innovative ways [1]. In [2], [3], the authors confirm that it can be any kind of information systems (such as TPS, MIS, DSS, EIS, OAS, ERP, etc.) that helps an organization: 1) gain a competitive advantage; 2) reduce a competitive disadvantage; and/or 3) meet other strategic organization objectives. Hence, any IS has the ability to change the goals, processes, products, or environmental relationships to help an organization gain a competitive advantage or reduce a competitive disadvantage is a strategic IS [1], [4].

In addition, the SIS involves using information technology to develop products, services, and capabilities that give a company strategic advantages over the competitive forces it faces in the global marketplace [2]. The advances in information provision have led organizations to attempt to develop IS or IT strategies align with their business strategies to achieve many benefits [1]. Such as helping the organization to reduce overall costs, get fewer errors and greater accuracy when performing operations, produce highquality products and services, accelerate communication and data sharing, improve performance and productivity, and make management more efficient and effective. Moreover, it gives the managers the ability to adjust, control and monitor all business processes which accordingly will accelerate the processes of the decision-making [3], [5]-[7]. 
In this context, the purpose of this paper is to highlight the role of Strategic Information Systems (SIS) in supporting and achieving Competitive Advantage (CA); in order to obtain the higher level of operational efficiency, information quality and innovation on the Saudi banking sector.

\section{LITERATURE REVIEW}

The concept of Strategic Information Systems (SIS) was introduced for the first time in the field of information systems in the early 1980s by Dr. Charles Wiseman [8]. The strategic information systems have been established as a core activity in the governance and management of information technology in organizations. Moreover, they have become a very challenging subject for scientists and practitioners in the recent years [9], [10]. Strategic information systems are essential to help organizations succeed in today's highly competitive global business environment.

The organizations in the current IT age need to use information systems effectively which require an understanding of the organization, management, and information technology that form the systems [11]. It also requires an understanding that the mission of the information systems itself is changed and evolved from a focus on efficiency and effectiveness to a focus on organization performance as the foundation for competitiveness in a rapidly changing environment [12]. Therefore, the top managers should understand that the information systems alone cannot provide an enduring business advantage. In order to obtain the competitive advantage; it is important to develop appropriate strategies that help to use the IS/IT based systems effectively and provide means to manage them [11]. To achieve this goal, an increasing number of the organizations are turning to develop Information Systems Strategies (ISS) by applying one methodology or approach of Strategic Information Systems Planning (SISP) [13], which helps them to convert their conventional information systems to Strategic Information Systems (SIS).

Strategic Information Systems are systems that help organizations alter their business strategies, plans or structure. They are also used to hasten the reaction time of the environmental changes and aid the organization to achieve a competitive advantage over its competitors. Strategic information systems are the traditional or conventional information systems used in innovative ways [1]. The essential purpose of the strategic information systems is to help organizations to do things better [14]. They also aim to develop and maintain the IS/IT systems that support the business operations in an effective way [11].

They are as instrumental in achieving the organization's competitive objectives or other strategic objectives [3]. They help an organization gain a competitive advantage through its contribution to achieve the strategic goals and/or its ability to significantly increase the performance and productivity [4]. The main objective of SIS according to [1] is "to define the explicit connection between an organization's business plans and IS plans to better achieve the goals and objectives and to provide closer management control for the critical IS/IT systems".
However, the successful use of information systems in order to achieve a competitive advantage is difficult. It requires precise coordination of technology, organization, and management [15]. Although strategic information systems can support or shape organizational strategies and its success promises considerable and great benefits, but the failure to develop and implement them is common [16]. The implementation of strategic systems often requires extensive organizational change and a transition from one sociotechnical level to another. Such changes are called strategic transitions and are often difficult and painful to achieve [15]. In addition, there are several attempts that have been made to identify the opportunities that help in developing the strategic systems as competitive weapons. Nevertheless, the most instances of strategic information systems success are retrospective, and most organizations have no definite plan to develop effective strategic information systems. This leads to questions concerning how much IS managers really understand about the development of strategic systems [17], [18].

Laudon in [15] confirms that the top management must understand that not all strategic information systems are profitable, they can be expensive to build and easily copied by other firms so that strategic advantage is not always sustainable. Strategic information systems have to be built on the strengths of the company that cannot be easily imitated. It has been determined that lasting, sustainable competitive advantage can be gained from strategic information systems only if an organization possesses other resources as well. Such resources include 1) a well-developed and flexible information technology platform or a database to obtain the advantages; and 2) continual investment to maintain those advantages [19]. Therefore, some of the recommended conditions/actions should be followed before the development and implementation of strategic information systems in the Organization. These proposed conditions/actions ensure the successful deployment of strategic information systems, which are as follows:

- Active support of senior organization management not just MIS management — in the discovery of strategic opportunities and in the implementation process.

- Integration of planning for the strategic use of information systems into the overall organization strategic planning process.

- Direct reporting by those responsible for strategic use of information systems to the business managers of the area to be affected by the new system.

- Placement of control mechanisms in the hands of these business managers.

- Readiness for strategic use of information systems, implying the successful use of the MIS and technological platform already in place and experience with technological innovation [19].

In the light of the above, organizations should seek to apply one or more strategic information systems to obtain 
many benefits and strategic reasons. The literature classified the benefits of strategic IS under three classifications, which are the alignment and competitiveness as well as strategic analysis. The benefits under strategic analysis will support the organization to raise its efficiency, effectiveness and performance to the highest level. On the other hand, the benefits under both alignment and competitiveness will support the organization to achieve the sustainable advantages. The following are the main features and benefits of strategic information systems under each classification: 1) Strategic analysis (support decision-making process, increase organizational efficiency and effectiveness, support different organizational levels, increase productivity of employees, support coordination of work, increase quality, reduce costs, support reactions to change and create new strategic opportunities). 2) Competitiveness (develop/produce new product/services, obtain competitive advantages, increase organizational competitiveness, support innovation and improve market share). 3) Alignment focus (integrate IS strategic plan into business strategic plan, consolidate the operations by integrating distributed systems, create standards, improve knowledge and improve resource creativity and flexibility) [3], [5]-[7].

\section{DIMENSIONS THAT FORM THE ROLE OF SIS FOR ACHIEVING CA}

It is critical that the organizations understand how to build the competitive advantages from the strategic IS. They also should understand that this process involves understanding the needs of the stakeholders, and devising strategies to IS to effectively utilize the resources available (or which can be obtained). This in turn will increase the organizational performance that is sustainable and successful over the long term [20], [21]. In addition, many researchers confirmed that the competitive advantage is at the core of an organization's success or failure [4]. Ketchen et al. in [22] defined the competitive advantage as "the extent to which an organization has the competency to create a defensible position over its competitors as a result of critical management decisions based on established strategies which differentiate itself from its rivals" [22]. Moreover, these strategies should take into account the target market, the business' strengths and weaknesses, the business' goals and objectives, the product and service and the strategies of the competition; to be able to achieve the competitive advantages [20]. The feedback from some of the literature reviews concluded that the utilization of strategic information systems has a positive association with the competitive advantage by different dimensions such as increasing operational efficiency, improving information quality and encouraging innovation. The objective of this section is to clarify the dimensions that form the role of strategic information systems, which all previous studies agreed to consider these dimensions as a competitive advantage for delivering a higher level of organizational performance.

\section{A. Operational Efficiency}

Based on the literature review, the operational efficiency refers to the effective use of human and material resources to increase the output of products and services, reduce costs and maximize profits. It also reflects the capability of an organization to deliver products or services to its customers in the most cost-effective manner while still ensuring the high quality of its products and services. In addition, it means producing more products and services with no greater use of resources or maintaining the same level of production using fewer resources. Increasing or improving operational efficiency is a key component of the company's revenue growth and the competitive advantages achievement.

In order to achieve operational efficiency, the company needs to minimize the redundancy and waste while taking advantage of resources that contribute significantly to its success and benefiting from the best manpower, technologies and business processes. It is also achieved by streamlining the company's core processes to respond more effectively to the continually changing market forces [23], [24]. The process of reducing internal costs resulting from operational efficiency enables the company to achieve higher profit margins or be more successful in highly competitive markets [24] and this can be done by using several strategies and techniques such as SIS [25]. Philip in [26], believes that the operational efficiency is the strategic IS goal, especially when competitive advantage is the primary objective.

Therefore, the organizations should bear in their mind that the strategic IS for operational efficiency can be as important and productive as planning for competitive advantages [26].

\section{B. Information Quality}

Based on the literature review, information quality refers to the quality of outputs that information systems produced, which can be in the form of reports or online screens. The organizations should focus on assuring the reliability of data to increase the quality of the systems [27]. Therefore, the high quality of the systems leads to high quality of the information and services. The high quality of information and services helps organizations to manage their business processes, increase decision-making efficiency, improve organizational performance and perform their jobs efficiently and effectively [27], [28]. In addition, the information provided by ISs, which is inconsistent with the needs of users, will be subjected to heavy maintenance costs and disrupt the operations, resulting in an increase in the overall costs at the organization [27].

Moreover, the information systems processing is similar to production processing in manufacturing organizations. If the product (information) is not delivered on time (timeliness) and the product (information) does not conform to the needs (relevance) of customers (users), then the customers (users) will be dissatisfied and the firm will lose business [29]. So, the information quality has been typically regarded as a key strategic component of competitive advantage. It also helps to enhance the service and product quality in organizations [27], [28]. The organizations without the ability to assess the quality of their information, they cannot assess the status of their organizational performance and monitor their improvement [30].

This can be done by using strategic information systems, which will provide significant benefits by improving the quality of information that enables the decision-maker to 
further improve the quality of his/her decisions outcomes in order to obtain competitive advantages [31].

\section{Innovation}

The organizations frequently adopt innovations to gain capabilities and competitive advantages [32]. If organizations want to be competitive, they must also be innovative [33]. Rogers in [34], defined the processes of innovation as the development and implementation of introducing new ideas or new technologies, that lead to achieve the sustainable competitive advantages to the organization. The innovation capability of an organization depends closely on its intellectual and/or organizational knowledge assets and on its ability to employ these assets [35]. Adopting the innovations in organizations in order to achieve higher levels of competitiveness, will lead to produce lower-cost products with better quality compared to those competitors [36]. Moreover, the innovations are not just a process of developing new information systems or technologies to produce new products or services, but in many cases, are a process of creating new models and strategies for information systems or technologies to do business better in the face of change [33].

In addition, the innovations are a crucial driver for improving organizational performance and achieving sustainable competitive advantages [36]. Therefore, an organization needs to enable innovation to take place through employing IT experts with SIS skills and managerial IT skills to obtain the competitive advantages [27]. Finally, the corporate leaders and IT managers should view the SIS as part of their company's strategic innovation, which has been considered as an important tool for achieving the competitive advantages.

\section{RESEARCH CONCEPTUAL MODEL AND HyPOTHESES}

Based on the overall results, derived from other studies that are closely related to this research, the conceptual model is proposed. This model will be used for identifying and analyzing the nature of the problem, detailing exactly what is going to be researched and examining the arguments of others. It also will be used as a road map for empirical data collection and analysis, and to establish a comprehensive overview of applying the strategic information system as a competitive advantage tool, especially on Saudi Banking Sector. Fig. 1 shows the components of the research conceptual model including the role of Strategic Information Systems (SIS) which is the independent variable. In addition, the figure shows the Competitive Advantage (CA) and its dimensions which are operational efficiency, information quality and innovation as the study dependent variables.

Based on the literature review and research model, the main hypothesis of the research is given below:

H1: There is a positive association between the role of Strategic Information Systems (SIS) and Competitive Advantage (CA).

This branched into three dimensions that increase the competitive advantage:
$\boldsymbol{H 1} 1_{a}$ : There is a positive association between the role of Strategic Information Systems (SIS) and operational efficiency.

$\boldsymbol{H 1}_{\boldsymbol{b}}$ : There is a positive association between the role of Strategic Information Systems (SIS) and information quality.

$\boldsymbol{H 1}_{\boldsymbol{c}}$ : There is a positive association between the role of Strategic Information Systems (SIS) and innovation.

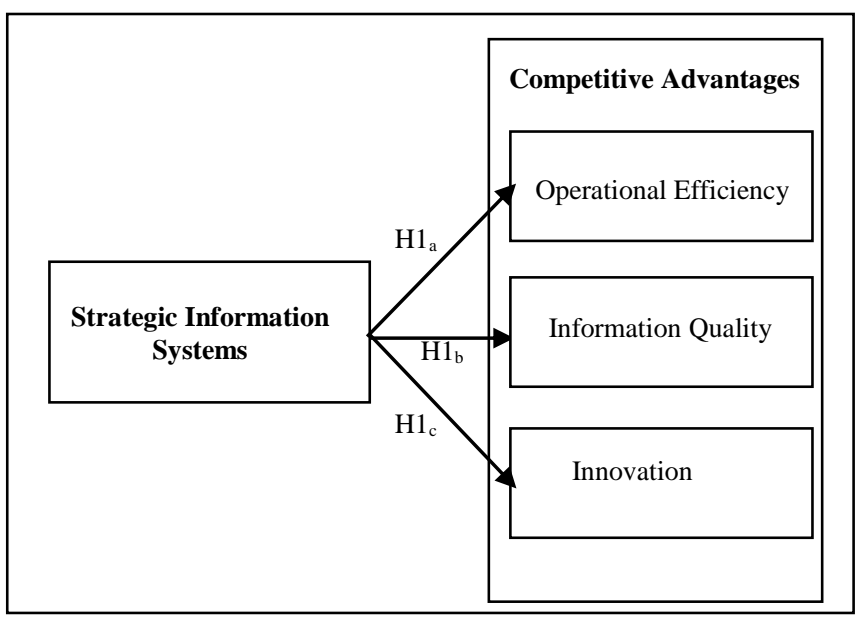

Fig. 1. The proposed conceptual model.

\section{RESEARCH DESIGN AND METHOD}

\section{A. Sampling}

The target population for this study consisted of the senior managerial level and the employees of various banking, regardless their size and location in Saudi Arabia. Researchers chose Saudi bank sector because it relies mainly on information systems when conducting their procedures. Therefore, it is important to measure the role of SIS in this sector.

In addition, random sampling was used as sampling technique so that each population member had an equal chance of being selected.

\section{B. Data Collection Procedure}

In order to collect the primary data for this empirical study and to test the research model and verify the hypotheses, the researchers developed survey; in the form of an electronic questionnaire. It is an electronic form containing a series of questions, and designed to extract specific information from respondents [37]. This method of data collection was considered appropriate because it is inexpensive and has the ability to collect a large amount of information from a large number of Bank employees in a short period of time. In addition, the survey is a popular research technique in obtaining quantitative data.

The survey instrument in this study consisted of 20 questions categorized into five main parts. The first part included questions related to demographic information of the respondents (e.g. gender, age, educational level, etc.). The other parts included the questions related to the measurement of the role of Strategic Information Systems (SIS) in supporting and achieving Competitive Advantage (CA) 
through the three dimensions which are operational efficiency, information quality and innovation.

\section{Data Analysis Procedure}

The fundamental purpose of the data analysis procedure is to achieve the research objectives and to find answers to the identified research questions and hypotheses. Davis suggested in [38] four primary steps that should be followed to conduct the data analysis, which are as following:

- Step 1: Selecting an analytical tool

- Step 2: Preparing the data for analysis

- Step 3: Identifying specific statistical techniques

- Step 4: Finally, presenting the analysis results [38].

In this study, the researchers followed these four steps to carry out the data analysis. Statistical Packages for the Social Sciences (SPSS) version (24) was used to analyze the collated data. However, after the selection of the analytical software and before the process of analysis, the raw data was prepared and cleaned to ensure the data has got no missing value or outliers. The SPSS was used to encode the data, and the examination was carried out to clean the data. This study did not find any missing values and hence proceeded to the next step. Thereafter, to meet the purposes of this study and to support the findings, the following statistical techniques were used and applied:

1) Cronbach's alpha coefficient to test the reliability and Spearman correlation analysis to test the validity,

2) Descriptive statistics technique which consists of frequency tables, measures of mean and measures of dispersion, to indicate respondents' degree of agreement or disagreement,

3) Pearson correlation analysis method to test the bivariate relationships between measured and latent variables in order to evaluate the hypotheses, and

4) Regression analysis to test the hypotheses.

The final step was the presentation and discussion of the analysis results which available in the following sections.

\section{Measurement instrument}

In this study, the researchers used a five-point Likert scale as a measuring instrument to indicate respondents' degree of agreement or disagreement with each of the last (15) statements, that ranged from "strongly agree (scored as 5) to "strongly disagree" (scored as 1). It is noted that the length of the interval (mane range) used here is $(4 / 5)$, or about 0.80 . It has been calculated on the basis that the five-scale Likert has kept among 4 distances [39]. It has been calculated on the basis that the five-scale Likert has kept among 4 distances [39]. Therefore, the scales and interval (mane range) have been translated in Table 1 .

TABLE I. LIKERT - SCALE AND GUIDELINES INTERVAL FOR EVALUATION AND INTERPRETATION

\begin{tabular}{|l|l|l|}
\hline Verbal Interpretation & Scale & Mean Range \\
\hline Strongly Disagree & 1 & $1.00-1.79$ \\
\hline Disagree & 2 & $1.80-2.59$ \\
\hline
\end{tabular}

\begin{tabular}{|l|l|l|}
\hline Neutral & 3 & $2.60-3.39$ \\
\hline Agree & 4 & $3.40-4.19$ \\
\hline Strongly Agree & 5 & $4.20-5.00$ \\
\hline
\end{tabular}

\section{DATA ANALYSIS AND RESULTS}

\section{A. Demographic profile}

The demographic profile of the respondents is illustrated in Table 2, which contains the frequency and percentage of demographic characteristics of the respondents studied.

TABLE II. The MAIN CHARACTERISTICS OF THE StUdy's SAMPLE

\begin{tabular}{|c|c|c|c|}
\hline $\begin{array}{l}\text { Demographic } \\
\text { Questions }\end{array}$ & Category & Frequency & $\begin{array}{l}\text { Percentag } \\
\text { e }\end{array}$ \\
\hline \multirow{2}{*}{ Gender } & Male & 85 & $57.8 \%$ \\
\hline & Female & 62 & $42.2 \%$ \\
\hline \multirow{4}{*}{ Age } & Less than 25 & 12 & $8.2 \%$ \\
\hline & 25 to 35 & 43 & $29.3 \%$ \\
\hline & 36 to 46 & 52 & $35.4 \%$ \\
\hline & More than 46 & 40 & $27.2 \%$ \\
\hline \multirow{3}{*}{ Education level } & Diploma or less & 0 & $0 \%$ \\
\hline & Bachelor degree & 75 & $51.1 \%$ \\
\hline & $\begin{array}{l}\text { Master's degree or } \\
\text { more }\end{array}$ & 72 & $48.9 \%$ \\
\hline \multirow{7}{*}{ Occupational Status } & Regional Manager & 3 & $2 \%$ \\
\hline & General Manager & 14 & $9.5 \%$ \\
\hline & Branch Manager & 18 & $12.2 \%$ \\
\hline & $\begin{array}{l}\text { Deputy Branch } \\
\text { Manager }\end{array}$ & 20 & $13.6 \%$ \\
\hline & Department Manager & 26 & $17.7 \%$ \\
\hline & Employee & 65 & $44.2 \%$ \\
\hline & Others & 1 & $0.7 \%$ \\
\hline \multirow{4}{*}{ Duration in position } & Less than 3 years & 32 & $21.8 \%$ \\
\hline & 3 to 6 years & 48 & $32.7 \%$ \\
\hline & 7 to 10 & 38 & $25.9 \%$ \\
\hline & More than 10 years & 29 & $19.7 \%$ \\
\hline
\end{tabular}

The collected data set in the study was 147 responses. The first question reveals that $57.8 \%$ of the samples were males compared to $42.2 \%$ females. In addition, $35.4 \%$ had age between 36 to 46 years. The educational levels of the respondents revealed that $51.1 \%$ had a bachelor degree, while $48.9 \%$ had a master's degree or more. Most of the respondents were from the employees represented by $44.2 \%$. Approximately, $32.7 \%$ of the respondents had between 3 to 6 years of experience in the position.

\section{B. Reliability Test}

The reliability refers to the probability that the same results would be obtained if the study were to be repeated at a later time, or with different samples [40]. The reliability in this study was calculated through measuring Cronbach's coefficient alpha. Which is the most common indicator used for assessing the internal consistency of the data postgathering to reflect the homogeneity of the scale [41]-[43]. This coefficient had values which range between 0 and 1 . Hinton et al. in [44], suggest four indicators as a level of 
internal reliability (see Table 3). As a rule, if the value of Cronbach's alpha is closer and gets to 1.0 , it is better and the scale is considered reliable and acceptable [43], [45], [46]. In accordance with this recommendation, Cronbach's coefficient alpha will be acceptable when its value equal to or greater than 0.7 .

In this study, the value of Cronbach's alpha of the 15items was 0.953 , which means that the values higher than the minimum standard of recommended level and resulted in excellent-range scores (see Table 4).

TABLE III. LEVEL OF INTERNAL RELIABILITY

\begin{tabular}{|l|l|}
\hline Range & Reliability Result \\
\hline 0.90 and above & Excellent Reliability \\
\hline $0.70-0.90$ & High Reliability \\
\hline $0.50-0.70$ & High Moderate Reliability \\
\hline 0.50 and below & Low Reliability \\
\hline
\end{tabular}

TABLE IV. CRONBACH'S ALPHA OF THE 15-ITEMS

\begin{tabular}{|l|l|l|}
\hline No. of Items & Reliability & Reliability Result \\
\hline 15 & 0.953 & Excellent Reliability \\
\hline
\end{tabular}

TABLE V. CRONBach's AlPha of THE 4 MEASURING DimENSIONS

\begin{tabular}{|l|l|l|l|}
\hline Measuring Dimensions & No. of Items & Reliability & Result \\
\hline SIS & 6 & 0.887 & High \\
\hline Operational Efficiency & 3 & 0.839 & High \\
\hline Information Quality & 3 & 0.843 & High \\
\hline Innovation & 3 & 0.849 & High \\
\hline
\end{tabular}

\section{Validity Test}

In addition, the researchers conducted reliability analysis by grouping the items to the five measuring dimensions which they derived from the study conceptual model. The values of Cronbach's alpha of these measuring dimensions varied between 0.887 to 0.849 , which means that the alpha values of all measuring dimensions are higher than the minimum standard of recommended level and resulted in high-range scores (see Table 5). This indicates that the measure of reliability for this research revealed an appropriate level of internal consistency.

The validity in quantitative research refers to determine whether the research survey truly measures what it is intended to measure. Moreover, it also measures the truthfulness of the research findings [47]. The type of validity test carried out in this study is construct validity. One of the methods used to establish the construct validity is the correlation analysis by calculating the value of Spearman's rho coefficient. This method tests the relationships between each item and the overall scale of its dimension that it belonged. The interpretation of the validity levels has been translated as follows in Table 6 . In general, if the value of correlations coefficients is closer gets to 1.0, the better and it is indicated that the scale is valid and it is measuring its intended concept [48], [49]. Table 7 shows the Spearman's rho correlation coefficient and validity results of the research instrument.
The values of Spearman's rho correlation indicate that the measure of validity for this research revealed an appropriate level of internal consistency. The results confirmed that the questionnaire was a valid measurement tool.

TABLE VI. LEVEL OF INTERNAL RELIABILITY

\begin{tabular}{|l|l|}
\hline Range & Validity Result \\
\hline 0.90 and above & Very-High Validity \\
\hline $0.70-0.90$ & High Validity \\
\hline $0.50-0.70$ & Moderate Validity \\
\hline 0.50 and below & Low Validity \\
\hline
\end{tabular}

TABLE VII. SPEARMAN's RHo CORRELATION VALUES TO MEASURE VALIDITY

\begin{tabular}{|c|c|c|}
\hline Item no. & Validity & Validity Result \\
\hline \multicolumn{3}{|c|}{ SIS (Independent Variable) } \\
\hline 1 & $0.835^{* *}$ & High Validity \\
\hline 2 & $0.813^{* *}$ & High Validity \\
\hline 3 & $0.750^{* *}$ & High Validity \\
\hline 4 & $0.821^{* *}$ & High Validity \\
\hline 5 & $0.768^{* *}$ & High Validity \\
\hline 6 & $0.819^{* *}$ & High Validity \\
\hline \multicolumn{3}{|c|}{ Operational Efficiency (OE) } \\
\hline 7 & $0.880^{* *}$ & High Validity \\
\hline 8 & $0.892^{* *}$ & High Validity \\
\hline 9 & $0.837^{* *}$ & High Validity \\
\hline \multicolumn{3}{|c|}{ Information Quality (IQ) } \\
\hline 10 & $0.891^{* *}$ & High Validity \\
\hline 11 & $0.884^{* *}$ & High Validity \\
\hline 12 & $0.845^{* *}$ & High Validity \\
\hline \multicolumn{3}{|c|}{ Innovation (INN) } \\
\hline 13 & $0.874^{* *}$ & High Validity \\
\hline 14 & $0.864^{* *}$ & High Validity \\
\hline 15 & $0.893^{* *}$ & High Validity \\
\hline \multicolumn{3}{|c|}{ CA (Dependent Variable) } \\
\hline OE & $0.918^{* *}$ & Very High Validity \\
\hline IQ & $0.936^{* *}$ & Very High Validity \\
\hline INN & $0.922^{* *}$ & Very High Validity \\
\hline
\end{tabular}

\section{Descriptive Statistics}

Descriptive statistics used to convert the raw data into useful information which can be interpreted to explain a group of dimensions [50].

The descriptive statistics for all items related to the five measuring dimensions included in the study are present in Tables 8 to 12 . These tables contain the percentage, frequency distribution, mean and standard deviation scores. They also show the satisfaction of respondents for each item and dimension based on the interpretation of 5-Likert scale (see Table 1).

According to the analysis in Table 8 , the result of the average weighted mean of the first measuring dimension is equal to 4.11. This is equivalent to "agree" by five-scale Likert, which means that the respondents have thought that the strategic information systems have an effective role to improve the organizational performance. 
According to the analysis in Table 9, the result of the average weighted mean of the first dimension of $\mathrm{CA}$ is equal to 4.18. This is equivalent to "agree" by five-scale Likert, which means that the respondents have thought that the strategic information systems play an important role in increasing and enhancing the operational efficiency of the work within their organizations. This in turn will help to support and achieve the competitive advantage. Based on this argument, this study asserts that $\mathrm{H} 1_{\mathrm{a}}$ is true, which states that there is a positive association between the role of strategic information systems and operational efficiency.

According to the analysis in Table 10, the result of the average weighted mean of the second dimension of $\mathrm{CA}$ is equal to 4.24 . This is equivalent to "strongly agree" by fivescale Likert, which means that the respondents have thought that the strategic information systems play an important role in increasing and enhancing information quality within their organizations. This in turn will help to support and achieve the competitive advantage. Based on this argument, this study asserts that the $\mathrm{H} 1_{\mathrm{b}}$ is true, which states that there is a positive association between the role of strategic information systems and information quality.
According to the analysis in Table 11, the result of the average weighted mean of the third dimension of CA is equal to 4.28. This is equivalent to "strongly agree" by five-scale Likert, which means that the respondents have thought that the strategic information systems play an important role in increasing and enhancing the innovation of the work within their organizations. This in turn will help to support and achieve the competitive advantage. Based on this argument, this study asserts that the $\mathrm{H} 1_{c}$ is true, which states that there is a positive association between the role of strategic information systems and innovation.

According to the analysis in Table 12, the result of the average weighted mean of the dependent variable (CA) is equal to 4.23. This is equivalent to "strongly agree" by fivescale Likert, which means that the respondents have thought that the strategic information systems play an important role in supporting and achieving the competitive advantage. Based on this argument, this study asserts that the main hypothesis is true, which states that there is a positive association between the role of strategic information systems and competitive advantage.

TABLE VIII. DESCRIPTIVE STATISTICS, FOR THE INDEPENDENT VARIABLE [SIS] OF THE STUDY

\begin{tabular}{|c|c|c|c|c|c|c|c|c|c|c|}
\hline Independent variable (SIS) & & 1 & 2 & 3 & 4 & 5 & Total & Mean & S.D & Result \\
\hline \multirow{2}{*}{$\begin{array}{l}\text { The Bank's senior management is committed to } \\
\text { developing the necessary strategies for its } \\
\text { programs, activities and projects related to IS }\end{array}$} & Frequency & 3 & 4 & 13 & 90 & 37 & 147 & \multirow{2}{*}{4.05} & \multirow[b]{2}{*}{0.80} & \multirow[b]{2}{*}{ Agree } \\
\hline & Percentage & $2 \%$ & $2.7 \%$ & $8.8 \%$ & $61.2 \%$ & $25.3 \%$ & $100 \%$ & & & \\
\hline \multirow{2}{*}{$\begin{array}{l}\text { The Bank is keen to align the objectives and } \\
\text { strategic plans of IS with overall objectives and } \\
\text { strategic plans }\end{array}$} & Frequency & 1 & 3 & 16 & 75 & 52 & 147 & \multirow[b]{2}{*}{4.18} & \multirow[b]{2}{*}{0.76} & \multirow[b]{2}{*}{ Agree } \\
\hline & Percentage & $0.7 \%$ & $2 \%$ & $10.9 \%$ & $51 \%$ & $35.4 \%$ & $100 \%$ & & & \\
\hline \multirow{2}{*}{$\begin{array}{l}\text { The Bank's senior management is committed to } \\
\text { developing and reviewing the strategic plans of } \\
\text { IS to identify the necessary changes }\end{array}$} & Frequency & 1 & 2 & 25 & 83 & 36 & 147 & \multirow[b]{2}{*}{4.03} & \multirow[b]{2}{*}{0.73} & \multirow[b]{2}{*}{ Agree } \\
\hline & Percentage & $0.7 \%$ & $1.4 \%$ & $17 \%$ & $56.4 \%$ & $24.5 \%$ & $100 \%$ & & & \\
\hline \multirow{2}{*}{$\begin{array}{l}\text { The Bank's employees are involved in the } \\
\text { development and improvement of IS }\end{array}$} & Frequency & 4 & 8 & 12 & 68 & 55 & 147 & \multirow{2}{*}{4.10} & \multirow{2}{*}{0.96} & \multirow{2}{*}{ Agree } \\
\hline & Percentage & $2.7 \%$ & $5.4 \%$ & $8.2 \%$ & $46.3 \%$ & $37.4 \%$ & $100 \%$ & & & \\
\hline \multirow{2}{*}{$\begin{array}{l}\text { An adequate budget is allocated to build and } \\
\text { develop strategic plans of information systems }\end{array}$} & Frequency & 2 & 4 & 16 & 76 & 49 & 147 & \multirow{2}{*}{4.13} & \multirow{2}{*}{0.81} & \multirow{2}{*}{ Agree } \\
\hline & Percentage & $1.4 \%$ & $2.7 \%$ & $10.9 \%$ & $51.7 \%$ & $33.3 \%$ & $100 \%$ & & & \\
\hline \multirow{2}{*}{$\begin{array}{l}\text { The SIS that used in the Bank is a key source to } \\
\text { support the processes of decision making }\end{array}$} & Frequency & 1 & 6 & 15 & 68 & 57 & 147 & \multirow{2}{*}{4.18} & \multirow{2}{*}{0.83} & \multirow{2}{*}{ Agree } \\
\hline & Percentage & $0.7 \%$ & $4.1 \%$ & $10.1 \%$ & $46.3 \%$ & $38.8 \%$ & $100 \%$ & & & \\
\hline \multicolumn{8}{|l|}{ Average Weighted Mean } & 4.11 & 0.65 & Agree \\
\hline
\end{tabular}

TABLE IX. DESCRIPTIVE STATISTICS, FOR FIRST DIMENSION (OPERATIONAL EFFICIENCY)

\begin{tabular}{|c|c|c|c|c|c|c|c|c|c|c|}
\hline Dimension 1 (Operational Efficiency) & & 1 & 2 & 3 & 4 & 5 & Total & Mean & S.D & Result \\
\hline \multirow{2}{*}{$\begin{array}{l}\text { The ISs that used in Bank help in increasing the } \\
\text { coordination and integration of different } \\
\text { operations and units }\end{array}$} & Frequency & 1 & 7 & 13 & 78 & 48 & 147 & \multirow{2}{*}{4.12} & \multirow{2}{*}{0.81} & \multirow{2}{*}{ Agree } \\
\hline & Percentage & $0.7 \%$ & $4.7 \%$ & $8.8 \%$ & $53.1 \%$ & $32.7 \%$ & $100 \%$ & & & \\
\hline \multirow{2}{*}{$\begin{array}{l}\text { The ISs that used in Bank help in increasing the } \\
\text { operational efficiency and production }\end{array}$} & Frequency & 1 & 7 & 17 & 71 & 51 & 147 & \multirow{2}{*}{4.12} & \multirow{2}{*}{0.84} & \multirow{2}{*}{ Agree } \\
\hline & Percentage & $0.7 \%$ & $4.7 \%$ & $11.6 \%$ & $48.3 \%$ & $34.7 \%$ & $100 \%$ & & & \\
\hline \multirow{2}{*}{$\begin{array}{l}\text { The ISs that used in Bank have ability of to } \\
\text { provide information to all units despite the } \\
\text { increasing volume and diversity of the various } \\
\text { operations }\end{array}$} & Frequency & 1 & 5 & 9 & 71 & 61 & 147 & \multirow[b]{2}{*}{4.27} & \multirow[b]{2}{*}{0.78} & \multirow[b]{2}{*}{$\begin{array}{l}\text { Strongly } \\
\text { Agree }\end{array}$} \\
\hline & Percentage & $0.7 \%$ & $3.4 \%$ & $6.1 \%$ & $48.3 \%$ & $41.5 \%$ & $100 \%$ & & & \\
\hline \multicolumn{8}{|l|}{ Average Weighted Mean } & 4.18 & 0.70 & Agree \\
\hline
\end{tabular}


TABLE X. DESCRIPTIVE STATISTICS, FOR SECOND DIMENSION (INFORMATION QUALITY)

\begin{tabular}{|c|c|c|c|c|c|c|c|c|c|c|}
\hline Dimension 2 (Information Quality) & & 1 & 2 & 3 & 4 & 5 & Total & Mean & S.D & Result \\
\hline \multirow{2}{*}{$\begin{array}{l}\text { The current organizational structure of the Bank } \\
\text { helps to the rapid exchange of information and to } \\
\text { make better use of it. }\end{array}$} & Frequency & 1 & 8 & 9 & 69 & 60 & 147 & \multirow[b]{2}{*}{4.22} & \multirow[b]{2}{*}{0.84} & \multirow{2}{*}{$\begin{array}{l}\text { Strongly } \\
\text { Agree }\end{array}$} \\
\hline & Percentage & $0.7 \%$ & $5.4 \%$ & $6.1 \%$ & $46.9 \%$ & $40.9 \%$ & $100 \%$ & & & \\
\hline \multirow{2}{*}{$\begin{array}{l}\text { The information systems that used in Bank make it } \\
\text { easy to link administrative units together to get } \\
\text { information at any time and properly }\end{array}$} & Frequency & 1 & 8 & 9 & 72 & 57 & 147 & \multirow[b]{2}{*}{4.20} & \multirow[b]{2}{*}{0.83} & \multirow{2}{*}{$\begin{array}{l}\text { Strongly } \\
\text { Agree }\end{array}$} \\
\hline & Percentage & $0.7 \%$ & $5.4 \%$ & $6.1 \%$ & $49 \%$ & $38.8 \%$ & $100 \%$ & & & \\
\hline \multirow{2}{*}{$\begin{array}{l}\text { The bank provides an integrated knowledge base to } \\
\text { provide all administrative units with environmental } \\
\text { changes surrounding them }\end{array}$} & Frequency & 1 & 2 & 11 & 71 & 62 & 147 & \multirow[b]{2}{*}{4.30} & \multirow[b]{2}{*}{0.73} & \multirow[b]{2}{*}{$\begin{array}{l}\text { Strongly } \\
\text { Agree }\end{array}$} \\
\hline & Percentage & $0.7 \%$ & $1.4 \%$ & $7.5 \%$ & $48.3 \%$ & $42.1 \%$ & $100 \%$ & & & \\
\hline \multicolumn{8}{|l|}{ Average Weighted Mean } & 4.24 & 0.69 & $\begin{array}{l}\text { Strongly } \\
\text { Agree }\end{array}$ \\
\hline
\end{tabular}

TABLE XI. DESCRIPTIVE STATISTICS, FOR THIRD DiMENSION (INNOVATION).

\begin{tabular}{|c|c|c|c|c|c|c|c|c|c|c|}
\hline Dimension 3 (Innovation) & & 1 & 2 & 3 & 4 & 5 & Total & Mean & S.D & Result \\
\hline \multirow{2}{*}{$\begin{array}{l}\text { The ISs that used in Bank help to create } \\
\text { opportunities for the creativities and initiatives }\end{array}$} & Frequency & 1 & 3 & 13 & 62 & 68 & 147 & \multirow{2}{*}{4.31} & \multirow{2}{*}{0.77} & \multirow{2}{*}{$\begin{array}{l}\text { Strongly } \\
\text { Agree }\end{array}$} \\
\hline & Percentage & $0.7 \%$ & $2 \%$ & $8.8 \%$ & $42.2 \%$ & $46.3 \%$ & $100 \%$ & & & \\
\hline \multirow{2}{*}{$\begin{array}{l}\text { The ISs that used in Bank help to accelerate the } \\
\text { development of services and diversify them to } \\
\text { serve the needs of consumers }\end{array}$} & Frequency & 1 & 4 & 11 & 74 & 57 & 147 & \multirow{2}{*}{4.24} & \multirow{2}{*}{0.76} & \multirow{2}{*}{$\begin{array}{l}\text { Strongly } \\
\text { Agree }\end{array}$} \\
\hline & Percentage & $0.7 \%$ & $2.7 \%$ & $7.5 \%$ & $50.3 \%$ & $38.8 \%$ & $100 \%$ & & & \\
\hline \multirow{2}{*}{$\begin{array}{l}\text { The ISs that used in Bank facilitate the } \\
\text { processes of research and development }\end{array}$} & Frequency & 1 & 6 & 11 & 62 & 67 & 147 & \multirow{2}{*}{4.28} & \multirow{2}{*}{0.83} & \multirow{2}{*}{$\begin{array}{l}\text { Strongly } \\
\text { Agree }\end{array}$} \\
\hline & Percentage & $0.7 \%$ & $4.1 \%$ & $7.5 \%$ & $42.1 \%$ & $45.6 \%$ & $100 \%$ & & & \\
\hline \multicolumn{8}{|l|}{ Average Weighted Mean } & 4.28 & 0.68 & $\begin{array}{l}\text { Strongly } \\
\text { Agree }\end{array}$ \\
\hline
\end{tabular}

TABLE XII. DESCRIPTIVE STATISTICS, FOR THE DEPENDENT VARIABLE

\begin{tabular}{|l|l|l|l|}
\hline \multicolumn{1}{|c|}{ Dependent variable (CA) } & Mean & S.D & Result \\
\hline Dimension 1: Operational Efficiency & 4.18 & 0.70 & Agree \\
\hline Dimension 2: Information Quality & 4.24 & 0.69 & $\begin{array}{l}\text { Strongly } \\
\text { Agree }\end{array}$ \\
\hline Dimension 3: Innovations & 4.28 & 0.68 & $\begin{array}{l}\text { Strongly } \\
\text { Agree }\end{array}$ \\
\hline Average Weighted Mean & $\mathbf{4 . 2 3}$ & $\mathbf{0 . 6 5}$ & $\begin{array}{l}\text { Strongly } \\
\text { Agree }\end{array}$ \\
\hline
\end{tabular}

\section{E. Hypotheses Test}

In order to evaluate the hypotheses of this study, the researchers conducted two tests, which are the correlation analysis and simple linear regression analysis.

\section{- Correlation analysis}

To understand the positive relationship which appeared in descriptive analysis better, the researchers conducted correlation analysis by calculating the value of Pearson's Coefficient (r). This analysis helps to examine the strength and direction of the linear relationship between independent variable and dependent variables [51]. According to the results of this analysis (see Table 14) and the quantitative interpretation of the degree of linear relationship (see Table 13), positive and high-level relationship was found among the role of SIS, operational efficiency, information quality and innovation which in turn will help organizations to achieve a higher level of competitive advantages and thus will help them to optimize their organizational performance.
TABLE XIII. THE QUANTITATIVE INTERPRETATION OF THE DEGREE OF LINEAR RELATIONSHIP (ALTARES, 2005)

\begin{tabular}{|l|l|}
\hline \multicolumn{1}{|c|}{ Value of $\mathbf{r}$} & \multicolumn{1}{c|}{ Interpretation } \\
\hline \pm 1.00 & Perfect Positive (Negative) Correlation \\
\hline $\pm 0.91- \pm 0.99$ & Very High Positive (Negative) Correlation \\
\hline $\pm 0.71- \pm 0.90$ & High Positive (Negative) Correlation \\
\hline $\pm 0.51- \pm 0.70$ & Moderately Positive (Negative) Correlation \\
\hline $\pm 0.31- \pm 0.50$ & Low Positive (Negative) Correlation \\
\hline $\pm 0.01- \pm 0.30$ & Negligible Positive (Negative) Correlation \\
\hline 0.00 & No Correlation \\
\hline
\end{tabular}

TABLE XIV. PERSON CORRELATION VALUES OF RELATIONSHIP BETWEEN VARIABLES

\begin{tabular}{|l|c|c|c|c|}
\hline & CA & $\begin{array}{c}\text { Operational } \\
\text { Efficiency }\end{array}$ & $\begin{array}{c}\text { Information } \\
\text { Quality }\end{array}$ & Innovation \\
\hline Role of SIS & $0.864^{* *}$ & $0.801^{* *}$ & $0.819^{* *}$ & $0.778^{* *}$ \\
\hline \multicolumn{4}{|c|}{$* *$ Correlation is significant at the 0.01 level (2-tailed). }
\end{tabular}

\section{- Regression analysis}

After the correlation analysis results were analyzed, the simple linear regression analysis was performed with competitive advantage (CA), operational efficiency, information quality and innovation as the dependent variables and strategic information systems (SIS) as the independent 
variable. Tables 15 to 18 contain the values of $\left(\mathrm{R}^{2}, \mathrm{~F}, \mathrm{~T}, \beta\right.$ and .Sig).

As shown in Table 15, the significant of " $F$ " and " $\beta$ " values were (0.000) for the first dimension of the CA, which are less than the value of the confidence level (0.05). Furthermore, the value of $\mathrm{R}^{2}$ also found that the strategic information systems explain $(64.2 \%)$ of the variance of operational efficiency. In addition, the value of $\beta$ was 0.801 , this means there is a positive strong effect of SIS in Saudi Banking sector on operational efficiency, which in turn will help to achieve a higher level of competitive advantages.

As shown in Table 16, the significant of " $F$ " and " $\beta$ " values were 0.000 for the second dimension, which are less than the value of the confidence level (0.05). Furthermore, the value of $\mathrm{R}^{2}$ also found that the strategic information systems explain $67.1 \%$ of the variance of information quality. In addition, the value of $\beta$ was 0.819 , this means there is a positive strong effect of SIS in Saudi Banking sector on information quality, which in turn will help to achieve a higher level of competitive advantages.

As shown in Table 17, the significant of " $F$ " and " $\beta$ " values were 0.000 for the third dimension of $\mathrm{CA}$, which are less than the value of the confidence level (0.05). Furthermore, the value of $\mathrm{R}^{2}$ also found that the strategic information systems explain $60.5 \%$ of the variance of innovation. In addition, the value of $\beta$ was 0.778 , this means there is a positive strong effect of SIS in Saudi Banking sector on innovation, which in turn will help to achieve a higher level of competitive advantages.

As shown in Table 18, the significant of " $F$ " and " $\beta$ " values were 0.000 for the dependent variable, which are less than the value of the confidence level (0.05). Furthermore, the value of $\mathrm{R}^{2}$ also found that the strategic information systems explain $74.6 \%$ of the variance of competitive advantage. In addition, the value of $\beta$ was 0.864 , this means there is a positive strong effect of SIS in Saudi Banking sector, which in turn will help to achieve a higher level of competitive advantages.

Therefore, the regression analysis showed that the four research hypotheses results were statistically significant. It also, proved that they are supported. The research results are summarized in Table 19.

This means that:

H1: There is a significant positive association between the role of Strategic Information Systems (SIS) and Competitive Advantage (CA).

$\boldsymbol{H} \mathbf{1}_{\boldsymbol{a}}$ : There is a significant positive association between the role of Strategic Information Systems (SIS) and operational efficiency.

$\boldsymbol{H 1}_{\boldsymbol{b}}$ : There is a significant positive association between the role of Strategic Information Systems (SIS) and information quality.

$H_{\boldsymbol{c}}$ : There is a significant positive association between the role of Strategic Information Systems (SIS) and innovation.
TABLE XV. SIMPLE LINEAR REGRESSION BETWEEN SIS AND OPERATIONAL EFFICIENCY

\begin{tabular}{|l|l|l|l|l|}
\hline Dependent Variables & $\mathbf{R}^{2}$ & $\mathbf{F}$ & $\mathbf{T}$ & $\boldsymbol{\beta}$ \\
\hline \multirow{3}{*}{ Operational Efficiency } & .642 & 260.4 & 16.1 & .801 \\
\cline { 3 - 3 } & &. Sig. $=.000$ & &. Sig. $=.000$ \\
\hline
\end{tabular}

TABLE XVI. SIMPLE LINEAR REGRESSION BETWEEN SIS AND INFORMATION QUALITY

\begin{tabular}{|l|l|l|l|l|}
\hline Dependent Variables & $\mathbf{R}^{2}$ & $\mathbf{F}$ & $\mathbf{T}$ & $\boldsymbol{\beta}$ \\
\hline \multirow{3}{*}{ Information Quality } & .671 & 295.5 & 17.2 & .819 \\
\cline { 3 - 3 } \cline { 5 - 5 } & &. Sig. $=.000$ & &. Sig. $=.000$ \\
\hline
\end{tabular}

TABLE XVII. SIMPLE LINEAR REGRESSION BETWEEN SIS AND INNOVATION

\begin{tabular}{|l|l|l|l|l|}
\hline Dependent Variables & $\mathbf{R}^{2}$ & $\mathbf{F}$ & T & $\mathbf{B}$ \\
\hline \multirow{3}{*}{ Innovation } & .605 & 222.3 & 14.9 & .778 \\
\cline { 3 - 4 } & &. Sig. $=.000$ & &. Sig. $=.000$ \\
\hline
\end{tabular}

TABLE XVIII.SIMPLE LINEAR REGRESSION BETWEEN SIS AND CA

\begin{tabular}{|c|c|c|c|c|}
\hline Dependent Variables & $\mathbf{R}^{2}$ & $\mathbf{F}$ & $\mathbf{T}$ & $\boldsymbol{\beta}$ \\
\hline \multirow{2}{*}{ 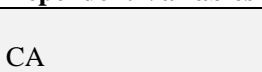 } & \multirow[t]{2}{*}{.746} & 426.9 & \multirow[t]{2}{*}{20.7} & .864 \\
\hline & &. Sig. $=.000$ & &. Sig. $=.000$ \\
\hline
\end{tabular}

TABLE XIX. HypotheSES Testing REsUlts

\begin{tabular}{|c|l|c|}
\hline HN & \multicolumn{1}{|c|}{ Description } & Results \\
\hline $\mathrm{H} 1$ & $\begin{array}{l}\text { There is a positive association between the role of } \\
\text { SIS and CA }\end{array}$ & Supported \\
\hline $\mathrm{H} 1_{\mathrm{a}}$ & $\begin{array}{l}\text { There is a positive association between the role of } \\
\text { SIS and operational efficiency. }\end{array}$ & Supported \\
\hline $\mathrm{H} 1_{\mathrm{b}}$ & $\begin{array}{l}\text { There is a positive association between the role of } \\
\text { SIS and information quality }\end{array}$ & Supported \\
\hline $\mathrm{H} 1_{\mathrm{c}}$ & $\begin{array}{l}\text { There is a positive association between the role of } \\
\text { SIS and innovation }\end{array}$ & Supported \\
\hline
\end{tabular}

\section{DISCUSSION}

It is clear from the literature review and the results of the study, that there is growing in the term of strategic information systems. This growth emerges with increased the competition intensity, which has made many business organizations adopt information systems with strategic impact. This type of systems called strategic information systems; and it has the ability to store, retrieve and analyze enormous data and information, that are invested to deal with the rapidly changing environment. Moreover, many researches confirmed that the SIS has a greater impact on the operational efficiency, information quality and innovation to gain competitive advantage, which are the dimension of the proposed conceptual model. On the other hand, the results of this study revealed that the weighted mean of these dimensions were $4.18,4.24$, and 4.28 , respectively with the average weighted mean for the competitive advantage (4.23). This means that the respondents have thought that the strategic information systems are tools to collect data and provide information to support the strategic decision-making process in order to 
achieve higher levels of competitive advantages. Moreover, the general statistical results of the correlation analysis and regression analysis of this study revealed that there is a positive and high-level relationship among the role of SIS with information quality $\left(. \mathrm{Sig}=.000, \mathrm{R}=.819^{* *}\right)$, operational efficiency ( $. \mathrm{Sig}=.000, \mathrm{R}=.801^{* *}$ ) and innovation ( $. \mathrm{Sig}=.000$, $\mathrm{R}=.778^{* *}$ ), respectively. This in turn will help organizations to achieve a higher level of competitive advantages (.Sig=.000, $\mathrm{R}=.864^{* *}$ ). Therefore, the officials of the departments in the Saudi banking sector should play an important role in directing senior managements and motivating them to use the strategic information systems to upgrade their knowledge skills and experience in this field.

Subsequently, it can be summarized that the information systems used in Saudi banking sector considered as strategic information systems. Moreover, they have been a significant role as competitive advantages tool to increase information quality, operational efficiency and innovation, respectively. This in turn indicates that the hypotheses proposed in this research are acceptable.

\section{PRACTICAL IMPLICATIONS}

The literature review of the strategic information systems has emphasized the fact that the organizations who implement the SIS projects will benefit from the competitive advantages they will receive and consequently will encourage the other competition organizations to adopt one or more of these strategic systems. Empirically, this research has shown that if the organizations develop the SIS projects, managers could achieve great competitive advantage; such increase in the operational efficiency, improve the information quality and encourage the innovation; only if carefully considered and developed. Then possibly this practice might spread the development of the SIS projects among all Saudi organizations. Furthermore, the main practical lesson that has emerged from the analysis presented in this study is:

- The full potential of strategic information systems is unlikely to be realized without an understanding of the significant challenges of developing the SIS and without understanding that the strategic impact is not always realized, even when the systems were strategically aligned and the implementation of IT was a success [18]. Therefore, more focus is needed to develop strategies based on the strengths of the organization that cannot be easily imitated, this will lead to minimize the negative impact of these challenges and achieve the sustainable competitive advantages.

\section{RESEARCH LIMITATION AND FUTURE RESEARCH}

This study was conducted in the banking sector in KSA context, and hence it is hard to decide whether the proposed conceptual model is applicable in other sectors and whether it could be applied in the context of other countries. This is due to several reasons, firstly: the lack of researches in other sectors that confirm the results; and secondly: the great differences in culture, values, beliefs, standards and knowledge between countries. Therefore, re-studying in other sectors or other countries will help to confirm and generalize the results. However, this study provides interesting opportunities for future SIS research, which need to be investigated and explored further. In addition, there are some recommended directions that could be further initiated. These are as follows:

- Future researchers should consider more comprehensive studies to identify the major consequences of strategic information systems as a tool to achieve the competitive advantages in a public sector, where the measuring of the competitive advantages in the public sector is difficult.

- Future researchers should consider more comprehensive studies to identify the major consequences of strategic information systems as a tool to achieve the competitive advantages with electronic businesses, such as e-government or e-commerce.

This may include studying more dimensions than these proposed in the conceptual model of this study.

\section{CONClusion}

Based on the findings of the study, the researchers concluded a set of recommendations that represent the importance of activating the role of the strategic information systems by the organizations in general and the Saudi banking sector in particular. The researchers confirmed that the organizations must be interested in SIS because of their impact on the continuity, growth and survival of them in the context of competition. The researchers also emphasized that the organizations should work on the introduction of SIS to improve the efficiency of operations and enhance the quality of information at the lowest cost and fastest time to enable the company to achieve the competitive advantages. In addition, the researchers emphasized the importance of developing specialized administrative units in aspects of strategic information systems that are entrusted with broader and more comprehensive functions than the departments of Management Information Systems (MIS). The researchers recommend that the organizations must involve their staff in training courses to 1) increase their skills and experience; 2) enable them to deal with strategic information systems which are characterized by the rapid development; and 3) enable them to meet the new work requirements. The researchers also strongly recommend that the organizations must pay sustained attention to the dimensions that can achieve, build and maintain the competitive advantages through the activation of strategic information systems roles. Especially that the organizations today operate in the international market, which is characterized by the sharp competition.

Ultimately, the researchers confirmed that the wellstructured strategic information systems would create a flexible framework to support the organizational capabilities and to improve the organizational performance. In addition, the SIS offers the opportunity to renovate the current operating environment and create a reliable, scalable and flexible platform to obtain the sustainable competitive advantages, get the brand differentiation, optimize the risk management and improve the decision-making efficiency. It enables the organizations in general and the Saudi banking 
sector in particular to gain and sustain competitive advantage in the marketplace by improving the operational efficiency, information quality and innovation of products and services.

However, it requires consideration of five key factors to realize and success of strategic information systems, which are: 1) active support of senior organization management not just MIS management — in the discovery of strategic opportunities and in the implementation process; 2) integration of planning for the strategic use of information systems into the overall organization strategic planning process; 3) direct reporting by those responsible for strategic use of information systems to the business managers of the area to be affected by the new system; 4) placement of control mechanisms in the hands of these business managers; and 5) readiness for strategic use of information systems, implying successful use of the MIS and technological platform already in place and experience with technological innovation [19]. By focusing on these five key factors, organizations can quickly increase operational efficiency, improve information quality and support innovation. These organizations will also devote themselves for supporting and achieving the sustainable competitive advantage in the coming years.

\section{REFERENCES}

[1] M. Rubel, M. Abul Kashem and N. Sultana, "Strategic Information System and Organizational Structure a Case on Meena Bazar Super Shop in Bangladesh." International Journal of Management (IJM), vol.5, no.4, pp. 50-65, 2014.

[2] H. Gupta, Management information system. New Delhi: International Book House, 2011.

[3] G. Marakas and J. O'Brien Introduction to information systems. New York, NY: McGraw-Hill/Irwin, 2013.

[4] M. Hemmatfar, M. Salehi and M. Bayat, "Competitive Advantages and Strategic Information Systems". IJBM, vol.5, no.7, pp.158-169, 2010.

[5] A. Basahel and I. Zahir, "Examining the Strategic Benefits of Information Systems: A Global Case Study," In European, Mediterranean \& Middle Eastern Conference on Information Systems (EMCIS). Abu Dhabi, UAE, 2010, pp. 1-17.

[6] E. Ankrah, "The Impact of Information System Strategy on Bank Performance in Ghana," Ph.D thesis, University of Ghana, Legon, Feb.2014

[7] V. Olufemi, Strategic Information System Planning (SISP) in Accenture, London : University of Roehampton, 2015.

[8] T. Liang and M. Tang,. "VAR analysis," ACM SIGMIS Database, vol.23, no.1, pp.27-35, 1992.

[9] F. Al-Aboud, "Strategic Information Systems Planning: A Brief Review," International Journal of Computer Science and Network Security, vol.11, no.5, pp.179-183, 2011.

[10] S. Maharaj and I. Brown, "The impact of shared domain knowledge on strategic information systems planning and alignment," $S$ Afr $j$ inf manag, vol,17, no.1, 2015.

[11] A. Issa-Salwe, M. Ahmed, K. Aloufi and M. Kabir, "Strategic Information Systems Alignment: Alignment of IS/IT with Business Strategy," Journal of Information Processing Systems, vol.6, no.1, pp.121-128, 2010.

[12] C. Gaines, D. Hoover, W. Foxx, T. Matuszek and R. Morrison, "Information systems as a strategic," Journal of Management and Marketing Research, 2012.

[13] R. Hoque, E. Hossin and W. Khan, "Strategic Information Systems Planning (SISP) Practices In Health Care Sectors Of Bangladesh," European Scientific Journal, vol.12, no.6, pp.307-312, 2016.

[14] M. Shirazi and J. Soroor, "An intelligent agent-based architecture for strategic information system applications," Knowledge-Based Systems, vol.20, no.8, pp.726-735, 2007.
[15] K. Laudon and J. Laudon, Essentials of management information systems, Upper Saddle River, NJ: Prentice Hall, 2005.

[16] M. Martinsons and A. Leung, "Strategic information systems: a success factors model," Int. J. Services Technology and Management, vol.3, no.4, pp.398-416, 2002.

[17] R. Kini, "Strategic Information Systems," Information Systems Management, vol.10, no.4, pp.42-45, 1993.

[18] V. Arvidsson, J. Holmström and K. Lyytinen, "Information systems use as strategy practice: A multi-dimensional view of strategic information system implementation and use," The Journal of Strategic Information Systems, vol.23, no.1, pp.45-61, 2014.

[19] V. Zwass, Foundations of information systems. Boston, Mass.: Irwin/McGraw-Hill, 1998.

[20] C. Ehmke and MS, "Strategies for competitive advantage," Department of Agricultural and Applied Economics, University of Wyoming, 2008.

[21] Z. Awino, "Business Strategy, Internal Resources, National Culture And Competitive Advantage: A Critical Review," In 1st DBA-Africa Management Review International Conference, 2015, pp.66-81.

[22] D. Ketchen, W. Rebarick, G. Hult and D. Meyer, "Best value supply chains: A key competitive weapon for the 21st century," Business Horizons, vol.51, no.3, pp.235-243, 2008.

[23] P. Jindal, "Operational efficiency of selected public-sector banks in India". Ph.D Thesis, Maharishi Markandeshwar University, Nov. 2013.

[24] N. Hussein, "Procurement Performance and Operational Efficiency in Telecommunication Industry in Kenya," Master thesis. University of Nairobi, Nov. 2014.

[25] T. Hovelja, A. Rožanec and R, Rupnik, "Measuring the Success of the Strategic Information System Planning in Enterprises in Slovenia" Management, vol.15, pp. 25-46, 2010.

[26] G. Philip, "IS Strategic Planning for Operational Efficiency," Information Systems Management, vol.24, no.3, pp.247-264, 2007.

[27] N. Gorla, T. Somers and B. Wong, "Organizational impact of system quality, information quality, and service quality," The Journal of Strategic Information Systems, vol.19, no.3, pp.207-228, 2010.

[28] Y. Al-Mamary, A. Shamsuddin and N. Aziati, "The Relationship between System Quality, Information Quality, and Organizational Performance," International Journal of Knowledge and Research in Management \& E-Commerce, vol.4, no.3, pp.7-10, 2014.

[29] B. Lam, "An Empirical Study of Factors Impacting School Management Based on Schools in Hoa Binh Province of Vietnam," Master thesis, Shu-Te University, June 2011.

[30] y. Lee, D. Strong, B. Kahn and R. Wang, "AIMQ: a methodology for information quality assessment," Information \& Management, vol.40, no.2, pp.133-146, 2002.

[31] A. Madapusi, "ERP Information Quality and Information Presentation Effect on Decision Making," SWDSI 2008 Proceedings, pp.628-633, 2008.

[32] K. Huang, R. Dyerson, L. Wu and G. Harindranath, "From Temporary Competitive Advantage to Sustainable Competitive Advantage," Brit J Manage, vol.26, no.4, pp.617-636, 2015.

[33] A. Afuah, Strategic innovation: New Game Strategies for Competitive Advantage. New York: Routledge, 2009.

[34] M. Rogers, "The Definition and measurement of innovation," Melbourne Institute Working Paper, vol.10, no.98, 1998.

[35] C. Martín-de, M, Delgado-Verde, J. Navas-López and J Cruz-González, "The moderating role of innovation culture in the relationship between knowledge assets and product innovation," Technological Forecasting and Social Change, vol.80, no.2, pp.351-363, 2013.

[36] H. Urbancova, "Competitive Advantage Achievement through Innovation and Knowledge," JOC, vol.5, no.1, pp.82-96, 2013.

[37] D. Nulty, "The adequacy of response rates to online and paper surveys: what can be done?," Assessment \& Evaluation in Higher Education, vol.33, no.3, pp.301-314, 2008.

[38] D. Davis, Business research for decision making, 1st e., Thomson/South-Western: Mason, OH, 2005.

[39] R. Likert, "A technique for the measurement of attitudes," Journal of Systems Management. Vol.22, no.140, pp. 44-53, 1932. 
[40] B. Ticehurst and A. Veal, Business research methods: a managerial approach, Longman: French Forest, NSW, 2000.

[41] M. Litwin, How to Measure Survey Reliability and Validity, 1st ed., Thousand Oaks: SAGE Publications, Incorporated, 1995.

[42] E. Carmines, and R. Zeller, Reliability and validity assessment, 1st ed., Newbury Park, Calif. [u.a.]: Sage Publ, 2008.

[43] M. Tavakol, and R, Dennick, "Making sense of Cronbach's alpha," International Journal Of Medical Education, vol.2, pp. 53-55, 2011.

[44] P. Hinton, C. Brownlow, L. McMurvay and B. Cozens, SPSS Explained. East Sussex, England: Routledge Inc, 2004.

[45] J. Pallant, The SPSS survival manual: A step-by-step guide to data analysis using SPSS for Windows (version 10), St Leonards, NSW: Allen \& Unwin., 2001.
[46] D. Straub, M. Boudreau and D. Gefen, Validation Guidelines for IS Positivist Research. Communications of the AIS, vol.13, no.1, pp. 380427, 2004.

[47] C. Kothari and G. Garg, Research methodology, 1st ed., New Delhi: New Age International (P) Limeted, 2016.

[48] J. Hair, Multivariate data analysis, 1st ed., Upper Saddle River [u.a.]: Prentice Hall, 2010.

[49] C. Robson and K. McCartan, Real world research. Chichester: Wiley, 2016.

[50] A. Bryman and E. Bell, Business research methods, 4th ed., Oxford: Oxford University Press, 2012.

[51] J. Pallant,. SPSS survival manual, 1st ed., Maidenhead, Berkshire, England: McGraw-Hill Education, 2016. 